\title{
Lens-specific Expression of Transforming Growth Factor $\beta 1$ in Transgenic Mice Causes Anterior Subcapsular Cataracts
}

\author{
Y. Srinivasan, F.J. Lovicu, and P.A. Overbeek \\ Department of Cell Biology, Baylor College of Medicine, One Baylor Plaza, Houston, Texas 77030
}

\begin{abstract}
Transgenic mice were generated by microinjection of a construct containing a self-activating human TGF- $\beta 1$ cDNA driven by the lens-specific $\alpha A$-crystallin promoter. Seven transgenic founder mice were generated, and four transgenic lines expressing TGF- $\beta 1$ were characterized. By postnatal day 21, mice from the four families exhibited anterior subcapsular cataracts. The lenses in these mice developed focal plaques of spindle-shaped cells that expressed $\alpha$-smooth muscle actin, and that resembled the plaques seen in human anterior subcapsular cataracts. Transgenic mice showed additional ocular defects, including corneal opacification and structural changes in the iris and ciliary body. The corneal opacities were associated with increased exfoliation of the squamous layer of the corneal epithelium and increased DNA replication in the basal epithelium. (J. Clin. Invest. 1998. 101:625-634.) Key words: TGF- $\beta$ • transgenic mice • cataracts $\bullet$ lens $\bullet$ cornea
\end{abstract}

\section{Introduction}

Transforming growth factor $\beta 1$ (TGF- $\beta 1$ ) and its two structurally and functionally related homologues, TGF- $\beta 2$ and TGF- $\beta 3$, are members of a large superfamily of secreted polypeptide growth factors that play crucial roles in cell proliferation, differentiation, migration, and extracellular matrix $(\mathrm{ECM})^{1}$ formation $(1,2,3)$. The three TGF- $\beta$ genes have different spatial and temporal patterns of expression, but the biological activi-

\begin{abstract}
Address correspondence to Paul A. Overbeek, Ph.D., Department of Cell Biology, Baylor College of Medicine, One Baylor Plaza, Houston, TX 77030. Phone: 713-798-6421; FAX: 713-790-1275; E-mail: overbeek@bcm.tmc.edu Y. Srinivasan's current address is Cardiovascular Research Institute, Box 0130, University of California San Francisco, San Francisco, CA 94804. F.J. Lovicu's current address is Department of Anatomy and Histology and Institute for Biomedical Research (F13), University of Sydney, Sydney, NSW 2006, Australia.

Received for publication 31 July 1997 and accepted in revised form 24 November 1997.
\end{abstract}

1. Abbreviations used in this paper: $\alpha$-SMA, $\alpha-$ smooth muscle actin; BrdU, 5-bromo-2'-deoxyuridine; E15, embryonic day 15; ECM, extracellular matrix; LAP, latency-associated peptide; P21, postnatal day 21; RPE, retinal pigmented epithelium; SV40, simian virus 40; T $\beta$ RI, TGF- $\beta$ receptor type I; T $\beta$ RII, TGF- $\beta$ receptor type II; TUNEL, terminal transferase-mediated dUTP-biotin nick end labeling.

J. Clin. Invest.

(C) The American Society for Clinical Investigation, Inc. 0021-9738/98/02/0625/10 \$2.00

Volume 101, Number 3, February 1998, 625-634

http://www.jci.org ties of the mature peptides are similar (4). The TGF- $\beta$ proteins are secreted as inactive complexes that contain the mature TGF- $\beta$ homodimer tightly associated with dimers of the amino-terminal domain (5) which is referred to as the latencyassociated peptide (LAP). The complexes are termed "latent" because they do not bind to TGF- $\beta$ receptors. The release of active TGF- $\beta$ from the latent complex may be regulated in vivo by specific proteases (6). TGF- $\beta$ can also be activated in vitro by acidic and basic conditions (7). Active TGF- $\beta 1$ stimulates cells by binding to TGF- $\beta$ type I and type II receptors (T $\beta R I$ and T $\beta$ RII, respectively), which are transmembrane serine threonine kinases. Ligand binding to T $\beta$ RII induces phosphorylation and activation of the T $\beta$ RI (8), which then signals to downstream pathways (9). Besides its role as a growth factor, TGF- $\beta 1$ also induces mesenchymal differentiation and functions as a potent chemotactic agent for several cell types, particularly monocytes (3). Fibroblasts are stimulated by TGF- $\beta 1$ to differentiate and produce increased levels of collagen and fibronectin (10).

The lens is an attractive model system to explore the role of growth factors in development, since both cell proliferation and differentiation occur in this tissue well into adulthood. The lens consists of only two cell types, epithelial and fiber cells. The continued growth of the lens occurs through mitosis of lens epithelial cells and differentiation of these cells into elongated fiber cells (11). Significant levels of expression of TGF- $\beta s$ have been detected in the eye of several mammalian species by immunohistochemistry and by in situ hybridization using isoform-specific probes (12-16). TGF- $\beta 1$ immunoreactivity has been demonstrated in the lens of the embryonic mouse eye (13) and in human photoreceptor cells (14). Aqueous humor samples from several different species, including humans, showed significant levels of latent TGF- $\beta 1$ and TGF- $\beta 2$ (15). In situ hybridization to embryonic mouse eyes using TGF- $\beta 2-$ specific riboprobes revealed high levels of expression in the lens epithelium and in the presumptive ciliary body (16). A recent study has established that TGF- $\beta 1,-\beta 2$, and $-\beta 3$ have distinct but overlapping patterns of expression in rat eyes. (Gordon-Thomson, C., R.U. de Iongh, A.M. Hales, C.G. Chamberlain, and J.W. McAvoy, manuscript submitted for publication). The presence of TGF- $\beta$ family members in the lens and surrounding tissues of the eye suggests that they may play various roles in development and maintenance of ocular tissues. In fact, mice deficient in bone morphogenetic protein 7 , another member of the TGF- $\beta$ family, are anophthalmic with extensive deterioration of the eye and optic nerve $(17,18)$. Mice that do not express TGF- $\beta 2$ also have ocular defects (19).

In certain metabolic disorders, or when stimulated by wounding, lens epithelial cells are induced to differentiate into fibroblast-like cells resulting in the formation of anterior subcapsular cataracts (20-23). Intact rat lenses (24) or lens epithelial explants (25) cultured in the presence of TGF- $\beta 2$ also develop changes typical of anterior subcapsular cataracts, such as the formation of spindle-shaped cells, wrinkling of the lens capsule, and accumulation of ECM (23). Therefore, it is likely 
that the levels of mature TGF- $\beta$ s are tightly controlled in the normal eye, and that intraocular TGF- $\beta$ s are present mostly as the biologically inactive latent forms.

To test the hypothesis that inappropriate TGF- $\beta$ activation in the eye can result in cataract formation, transgenic mice were generated that express a self-activating human TGF- $\beta 1$ under the control of the lens-specific $\alpha \mathrm{A}$-crystallin promoter. The transgenic mice developed anterior subcapsular cataracts and corneal opacities. In addition, the mice showed defects in the development of the anterior margins of the optic cup. Our results suggest that inappropriate activation of endogenous latent TGF- $\beta$ by proteases released after surgery or wounding of the eye may cause or contribute to the formation of human subcapsular cataracts. The transgenic mice described in this study provide a useful animal model for research on cataract induction and also for research on the control of corneal proliferation and differentiation.

\section{Methods}

\section{Construction of DNA for microinjection}

A cDNA encoding a modified human TGF- $\beta 1$ (pKR5 $\beta 1 \mathrm{EC} 2 \mathrm{~S} 2)$ was obtained from Dr. Rik Derynck (University of California, San Francisco). This plasmid encodes the wild-type mature TGF- $\beta 1$, but sitedirected mutagenesis was used to replace two cysteine codons in the TGF- $\beta 1$ propeptide with codons for serine (26). This modification results in secretion of a self-activating form of TGF- $\beta 1$ (27). The cDNA clone was digested with BglII, blunt-ended with T4 polymerase, then treated with $\mathrm{ClaI}$, and the $1.5-\mathrm{kb}$ cDNA was inserted into the polylinker site of the $\alpha \mathrm{A}$-crystallin promoter vector termed CPV2 $(28,29)$ cut with ClaI and SmaI. The CPV2 vector contains the small $t$ intron and early region polyadenylation sequences from simian virus 40 (SV40) (30). A 2.8-kb fragment containing the TGF- $\beta 1$ minigene (Fig. 1) was released from the plasmid by digestion with NotI, isolated by agarose gel electrophoresis, and purified for microinjection by extraction using the QIAEX gel extraction kit from QIAGEN Inc. (Chatsworth, CA).

\section{Generation of transgenic mice}

The use and treatment of mice in this study conformed to the Association for Research in Vision and Ophthalmology Statement for the Use of Animals in Ophthalmology and Vision Research, and the National Institutes of Health Guidelines for the Care and Use of Laboratory Animals. The purified TGF- $\beta 1$ minigene fragment was microinjected at a concentration of $2 \mathrm{ng} / \mu \mathrm{l}$ into individual pronuclei of FVB/N embryos (31). FVB/N mice are homozygous for the retinal degeneration $(r d)$ mutation (31). Injected embryos were transferred into pseudopregnant ICR females. Potential transgenic mice were screened by isolating genomic DNA from tail biopsies (32) and testing for transgenic sequences by PCR using primers specific for the SV40 sequences (33).

\section{In situ hybridization}

TGF- $\beta 1$ transgene. An EcoRI/XbaI fragment of CPV2 containing the entire 847-bp SV40 intron and polyA region was subcloned into pBluescript KS - (Stratagene Inc., La Jolla, CA) to generate sense and antisense $\left[{ }^{35} \mathrm{~S}\right] \mathrm{UTP}$-labeled riboprobes with T7 or T3 RNA polymerase. Tissue sections were prepared, and in situ hybridizations were performed as described previously (33). Tissues were counterstained with Harris hematoxylin. Hybridizations were performed on embryos collected from timed pregnancies (morning of copulation plug $=$ day 0 ).

Endogenous expression of TGF- $\beta 1$. A 985-bp wild-type rat TGF- $\beta 1$ cDNA (34) subcloned in pBluescript II KS + vector was used to generate sense and antisense riboprobes.

Expression of TGF- $\beta$ receptors. To localize endogenous expres- sion of T $\beta R I$ and T $\beta R I I$, riboprobes were generated from mouse cDNA clones $(35,36)$. A 1,060-bp BglII/NotI fragment of the mouse T $\beta R I I$ cDNA and a 700-bp XbaI/NotI fragment from the T $\beta R I$ cDNA were cut out and subcloned into pBluescript KS - cut with the same enzymes. The plasmids were linearized, and riboprobes were generated using T3 and T7 RNA polymerases.

\section{Histology and immunohistochemistry}

Histology. Eyes or embryonic heads were removed and fixed for $24 \mathrm{~h}$ in $10 \%$ neutral buffered formalin, dehydrated in ethanol, cleared in xylene, and embedded in paraffin wax for sectioning. Sections $(5 \mu \mathrm{m})$ were stained with hematoxylin and eosin or with periodic acid-Schiff (PAS) reagent. To detect cells in the $\mathrm{S}$ phase of the cell cycle, the incorporation of 5-bromo- 2 '-deoxyuridine (BrdU) was analyzed using antibodies to BrdU as described previously (37).

Expression of the TGF- $\beta 1$ LAP. Detection of LAP in the eyes of transgenic and control animals was carried out using a polyclonal anti-human TGF- $\beta 1$ LAP antibody made in goat (AB-246-PB; R \& D Systems, Inc., Minneapolis, MN). Histological sections were deparaffinized by xylene treatment twice for $10 \mathrm{~min}$ each, then hydrated and washed in PBS (10 mM sodium phosphate, $\mathrm{pH} 7.2,0.1 \mathrm{M} \mathrm{NaCl}$ ) three times for $5 \mathrm{~min}$ each. Sections were then preincubated with $10 \%$ methanol, $3 \% \mathrm{H}_{2} \mathrm{O}_{2}$ in PBS for 30 min to block endogenous peroxidases. Sections were subsequently incubated with normal rabbit serum for $1 \mathrm{~h}$ at room temperature to block nonspecific binding, then incubated with goat anti-human TGF- $\beta 1$ LAP antibody, $5 \mu \mathrm{g} / \mathrm{ml}$, overnight at $4^{\circ} \mathrm{C}$. Negative controls without primary antibody were included. Immune complexes were visualized using the avidin-biotin peroxidase complex method (ABC kit; Vector Laboratories, Inc., Burlingame, CA) and diaminobenzidine as the substrate. Sections were counterstained with hematoxylin.

Detection of $\alpha$-smooth muscle actin ( $\alpha$-SMA). Eyes from 21-d-old (P21) mice were processed as described above. An anti- $\alpha$-SMA mouse mAb (A2547; Sigma Chemical Co., St. Louis, MO) was used at 1:100 dilution. Sections were blocked with normal horse serum and visualized using a horse anti-mouse secondary antibody and the $\mathrm{ABC}$ kit, followed by hematoxylin counterstaining.

Detection of T $\beta R I$ and T $\beta R I I$. Purified polyclonal antipeptide antibodies specific for either T $\beta R I$ (sc 398) or T $\beta R I I$ (sc 220) were obtained from Santa Cruz Biotechnology, Inc. (Santa Cruz, CA) and used at a concentration of $2 \mu \mathrm{g} / \mathrm{ml}$.

Detection of $\beta$-crystallin. $\beta$-Crystallins were detected in lenses of transgenic or control animals using a specific antibody as described (33).

\section{Results}

\section{TGF- $\beta 1$ transgenic mice}

A construct encoding the C2S2 version of human TGF- $\beta 1$ (see Fig. 1), driven by the $\alpha$ A-crystallin promoter, was used to generate transgenic mice expressing human TGF- $\beta 1$ specifically in the lens. The transgenic cDNA encodes a full-length TGF- $\beta 1$ propeptide that is processed to produce active TGF- $\beta 1$ and the LAP. The minigene was microinjected into FVB/N mouse embryos, and seven transgenic founder mice designated OVE 852, OVE 853, OVE 854, OVE 917, OVE 918, OVE 919, and OVE 920 were obtained. Transgenic mice from three families (OVE 853, OVE 918, and OVE 919) developed similar ocular phenotypes that were apparent by P21 and that included both corneal opacities and cataracts (Fig. $1 B$ ). In one family (OVE 920), the phenotype was more severe, and microphthalmia was evident (data not shown). The phenotypic differences suggest that there are differences in the expression levels for the different transgenic integration sites. Analogous studies from our laboratory on transgenic mice expressing a fibroblast growth factor (FGF)- $4 \mathrm{cDNA}$ linked to the same $\alpha \mathrm{A}$-crystallin promoter showed that there is a good correlation between the se- 

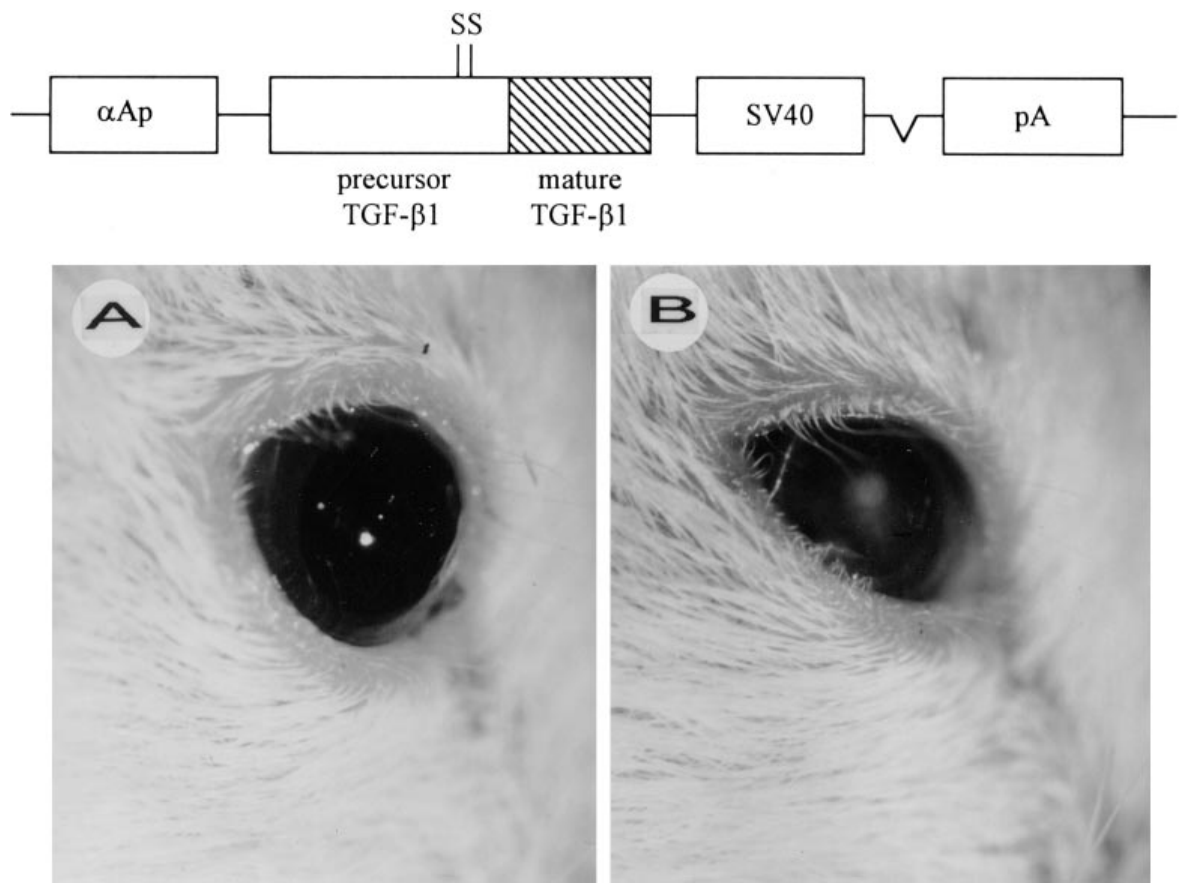

Figure 1. Schematic drawing of the TGF- $\beta 1$ minigene and external ocular appearance of mice expressing the TGF- $\beta 1$ cDNA in the lens. A human C2S2 TGF- $\beta 1$ cDNA was inserted into a polylinker downstream of the $\alpha$ A-crystallin promoter $(\alpha A p)$. The cysteine to serine mutations $(S S)$, LAP (precursor), and the mature TGF- $\beta 1$ are indicated. The minigene used for microinjection contains the mouse $\alpha \mathrm{A}$-crystallin promoter, human TGF- $\beta 1$ cDNA, and SV40 intron and polyadenylation $(p A)$ sequences. $(A)$ A nontransgenic mouse. $(B)$ A transgenic mouse (line OVE 853) with an anterior subcapsular cataract and corneal opacity. Both mice were $10 \mathrm{wk}$ old.

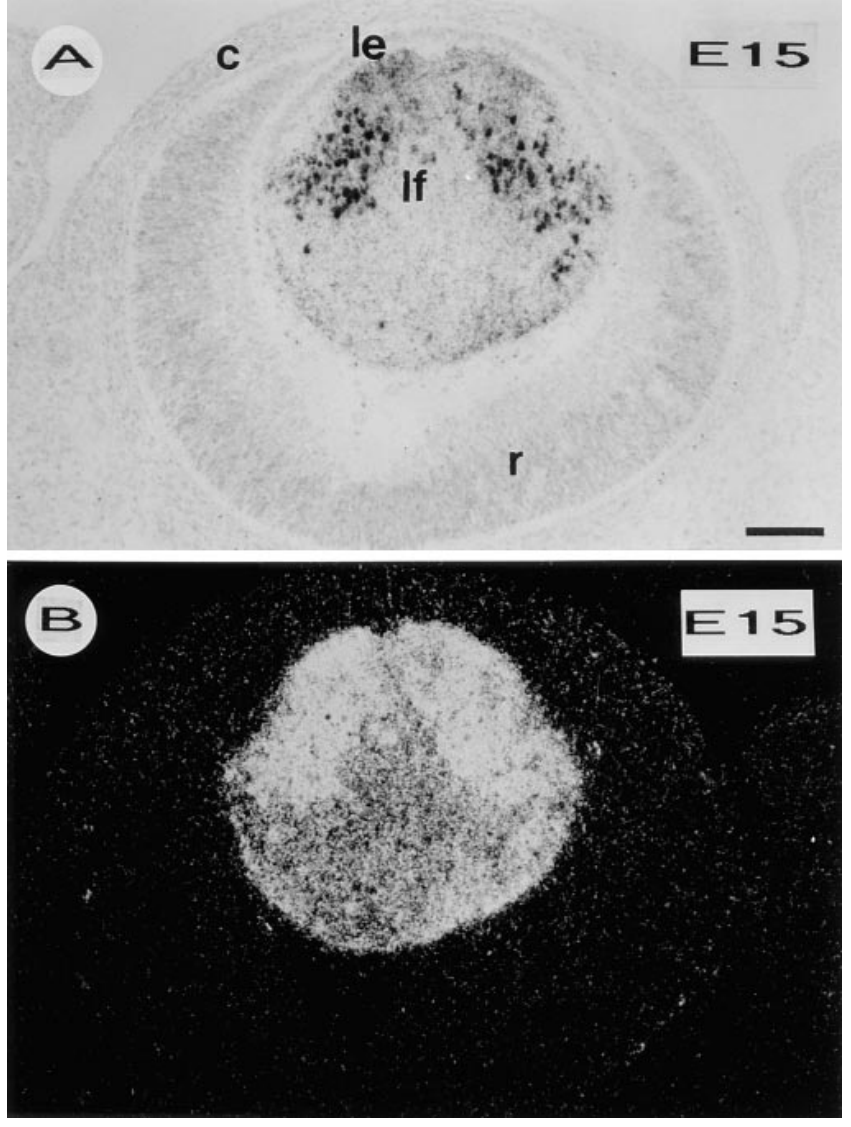

Figure 2. Lens-specific expression of the transgene. Histology sections of embryonic heads of transgenic mice from line OVE 853 at E15 were used for in situ hybridizations to a probe specific for the SV40 sequences of the transgene. A bright field view $(A)$ and corresponding dark field view $(B)$ of a section through one embryonic eye are shown. The slides were exposed to emulsion and stored for $2 \mathrm{~d}$ at verity of the transgenic phenotype and the level of transgene expression (Lovicu, F.J., and P.A Overbeek, manuscript submitted for publication). In this study, since the TGF- $\beta 1$ transgenic families with cataracts demonstrated similar ocular histology, they will be described collectively, represented by mice from transgenic family OVE 853.

To assay for transgene expression, in situ hybridization was performed using a transgene-specific riboprobe corresponding to the SV40 sequences (see Fig. 1). Beginning soon after lens formation, transgenic transcripts were expressed at high levels exclusively in the lens fiber cells of transgenic mice (Fig. 2). No specific hybridization was observed using this riboprobe in nontransgenic littermates or when using a sense-strand riboprobe (data not shown).

Immunohistochemistry was used to analyze the expression pattern and level of the transgenic protein using an antibody raised against the LAP of human TGF- $\beta 1$ (Fig. 3). In embryonic day 15 (E15) lenses, high levels of TGF- $\beta 1$ LAP were detected in lenses of OVE 853 transgenic mice (Fig. $3 \mathrm{~B}$ ) and not in nontransgenic littermate controls (Fig. $3 A$ ). Although staining was detected predominantly in the lenses of transgenic mice, reactivity was also observed in the anterior optic cup (presumptive iris and ciliary body), in the retinal pigmented epithelial cells (RPE), and in the corneal epithelium (Fig. 3 B). Interestingly, in nontransgenic mice, weak reactivity was detected in the vasculature surrounding the lens and in the corneal epithelium, indicating that the antibody may detect endogenous TGF- $\beta$ l LAP (Fig. $3 A$ ).

$4^{\circ} \mathrm{C}$ before developing. Transgenic transcripts were detected only in the lens fiber cells $(l f)$. No hybridization was detected in wild-type eyes or when using a sense probe (data not shown). c, Cornea. le, Lens epithelium. $r$, Retina. Scale bar $=100 \mu \mathrm{m}$. 


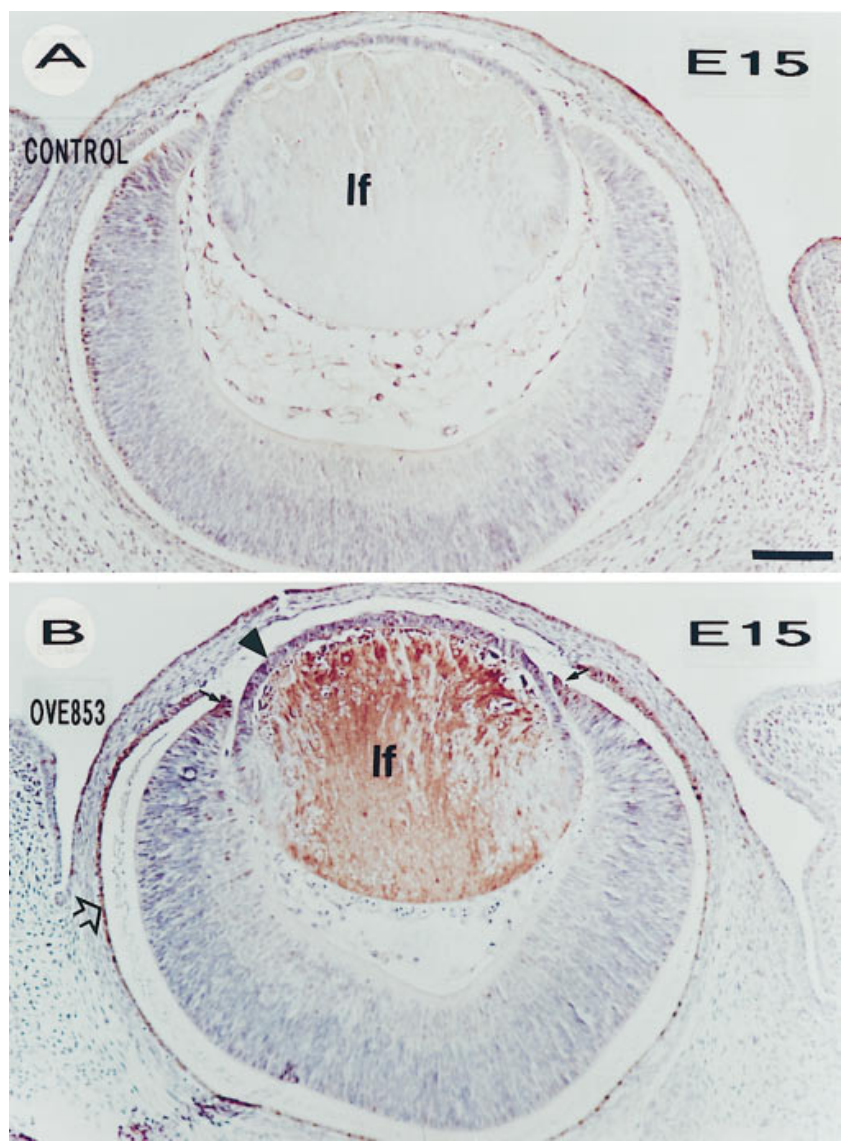

Figure 3. Immunohistochemistry to detect transgenic TGF- $\beta 1$ LAP protein. The distribution of TGF- $\beta 1$ LAP was examined in the eyes of nontransgenic $(A)$ and transgenic $(B)$ mice from line OVE 853 at E15 using an antibody to human TGF- $\beta 1$ LAP which is encoded by the transgenic cDNA. Brown, Presence of the protein. TGF- $\beta 1$ LAP $(B)$ was detected in the lens fiber cells $(l f)$, anterior optic cup (black arrows), RPE (open arrow), and lens epithelium (arrowhead) of transgenic eyes. The corneal epithelial cells showed positive staining in both the nontransgenic and the transgenic eyes $(A$ and $B)$. Scale bar $=100 \mu \mathrm{m}$.

\section{Histological analysis of TGF- $\beta 1$ transgenic mice}

Increased proliferation and exfoliation of corneal epithelial cells in transgenic mice. Although high levels of TGF- $\beta 1$ mRNA and protein are expressed in lenses of transgenic mice at E15 (see Figs. $2 B$ and $3 B$ ), we did not detect any phenotypic differences at this age or in neonatal eyes (data not shown). However, by P21 (Fig. 4), abnormalities became apparent in four of the transgenic families. In nontransgenic eyes, the corneal surface is composed of a well-defined stratified squamous epithelium (Fig. 4 C). In comparison, the corneal epithelium of transgenic eyes is composed of only two to three layers of cells, undergoing premature exfoliation, and the corneal stromal layer is thicker than that of nontransgenic littermates (Fig. 4D). The transgenic mice also demonstrated prominent defects in their irises and ciliary bodies. In many transgenic eyes, the irises were attached to the posterior region of the cornea (see Fig. $4 F$ ), and the ciliary body was absent or severely underdeveloped (see Fig. $4 H$ ).
We compared DNA synthesis in P21 eyes of transgenic and nontransgenic mice by examining the patterns of BrdU incorporation. A prominent difference in DNA synthesis was observed only in the cornea, with a marked increase in incorporation of BrdU in the basal corneal epithelium of transgenic mice (Fig. $5 D$ ).

Cataract formation. By P21, in addition to the corneal and other ocular changes described above, the transgenic animals developed fibrotic plaques in the subepithelial region underlying the anterior lens capsule (Fig. $4 D$ ), accounting for the cataracts observed in these mice (see Fig. 1). Unlike the cuboidal monolayer of lens epithelial cells present in nontransgenic eyes (Fig. $4 \mathrm{C}$ ), the anterior region of the lens in transgenic mice had an abnormal plaque of spindle-shaped cells that appeared to arise by phenotypic conversion from the lens epithelium (Fig. $4 \mathrm{D}$ ). These phenotypic changes persisted and were still prominent in adult mice (data not shown). However, there was no evidence of BrdU incorporation in cells comprising these anterior subcapsular plaques in transgenic lenses (Fig. $5 B$ ).

Expression of markers for anterior subcapsular cataract. The fibrous plaques of cells found in the anterior regions of the transgenic lenses morphologically resemble the previously described histology of anterior subcapsular cataracts (20-23). To further characterize these plaques, the transgenic lenses were stained using PAS to examine changes in the distribution of ECM. PAS staining of P21 nontransgenic lenses revealed prominent staining of only the lens capsule (Fig. $6 \mathrm{~A}$ ). However, in transgenic lenses, not only did the lens capsule stain, but prominent staining for ECM was also observed in the cataractous plaque, interspersed between the fibroblast-like cells (Fig. $6 \mathrm{~B}$ ). Interestingly, PAS staining of transgenic lenses also highlighted the irregular profile of the capsule surface overlying the subcapsular plaque (Fig. $6 \mathrm{~B}$ ), in comparison to the smooth capsule surface of nontransgenic lenses (Fig. 6A).

A specific marker for anterior subcapsular cataracts is $\alpha$-SMA (38), a protein not normally expressed in the lens. Immunohistochemistry using a specific antibody to $\alpha$-SMA on sections of lenses from P21 transgenic mice showed strong staining in the fibrous plaque derived from the lens epithelium (Fig. $6 \mathrm{D}$ ). Epithelial cells that remained in a monolayer in transgenic lenses also showed specific staining for this marker, indicating that they had been affected by the transgenic TGF- $\beta 1$. In nontransgenic mice, no specific staining for $\alpha$-SMA was observed in the lens (Fig. $6 \mathrm{C}$ ). Immunostaining of the subcapsular cataractous plaques in transgenic lenses with an antibody to $\beta$-crystallin, a lens-specific molecular marker of fiber cell differentiation, showed no staining in these cells (data not shown), indicating that these plaques are not comprised of abnormal fiber cells.

To determine if the cells in the subcapsular plaque of transgenic mice were undergoing programmed cell death, we carried out a TUNEL (terminal transferase-mediated dUTPbiotin nick end labeling) assay (39) on sections of eyes from P21 transgenic and nontransgenic mice. At this stage of postnatal development, no TUNEL-positive cells were observed in the plaque of transgenic lenses or in lenses of nontransgenic mice (data not shown).

\section{Endogenous expression of TGF- $\beta 1$ and TGF- $\beta$ receptor subtypes in the developing eye}

As different ocular tissues were responsive to expression of active TGF- $\beta 1$, we examined expression of endogenous TGF- $\beta 1$ 


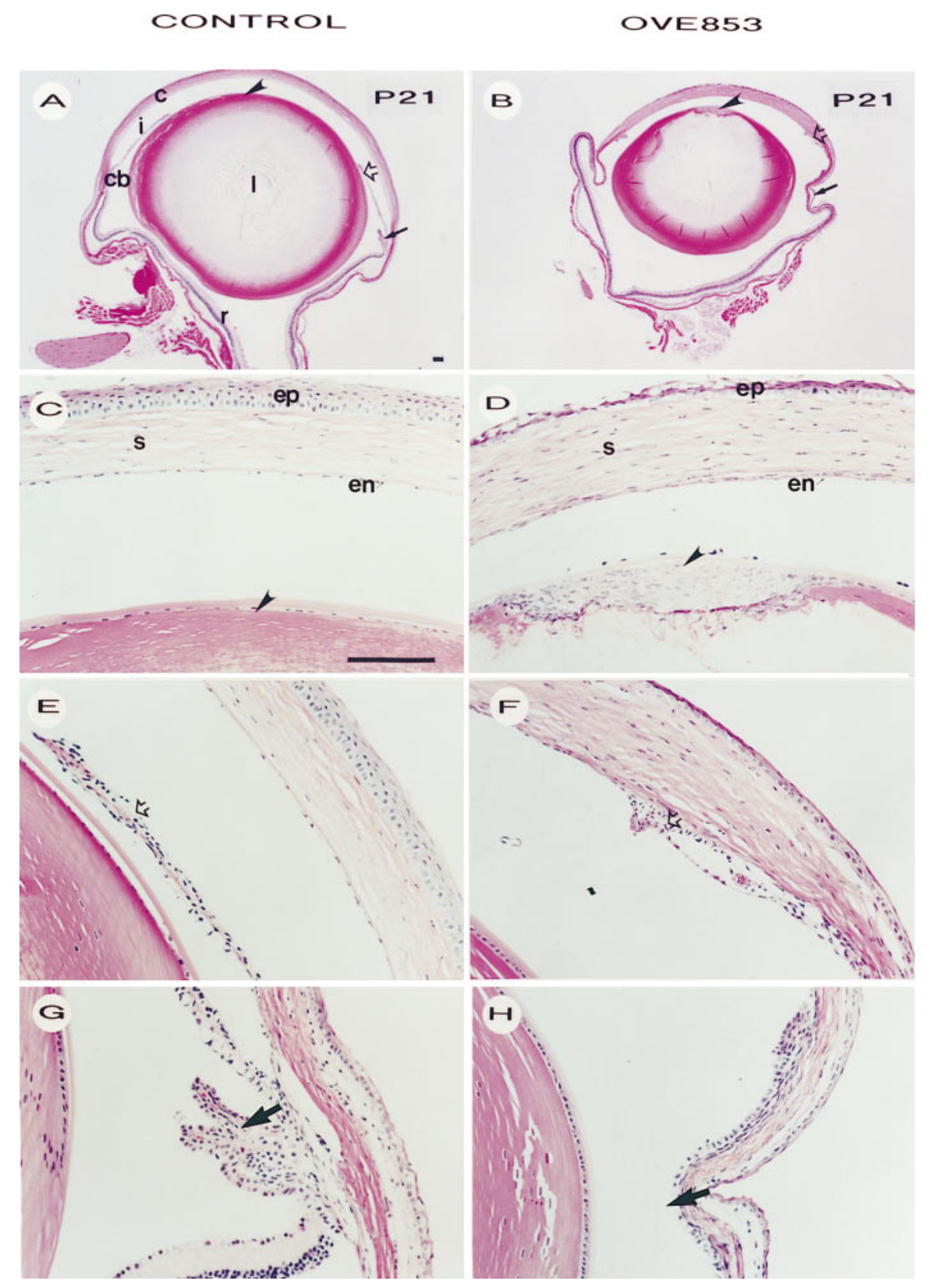

Figure 4. Histological examination of $\mathrm{P} 21$ eyes from nontransgenic $(A, C, E$, and $G)$ and transgenic $(B, D, F$, and $H)$ mice of line OVE 853. The overall morphology of the nontransgenic $(A)$ and transgenic $(B)$ eyes is shown in the top two panels. Shown at higher magnification are the cornea and anterior lens $(C$ and $D)$, the iris $(E$ and $F)$ and the ciliary body $(G$ and $H)$. Note the presence of a subcapsular fibrotic plaque ( $B$ and $D$, arrowheads) in the transgenic lens but not in the control lens $(A$ and $C)$. Note also the altered architecture of the cornea of the transgenic eye (compare $C$ and $D$ ). The corneal stroma (s) of the transgenic eye is thicker, whereas the epithelial cells $(e p)$ are disorganized and undergoing exfoliation. Corneal endothelial cells (en) in the transgenic eye are missing or not properly organized. The iris in the transgenic eyes $(F$, open arrow $)$ is deformed and attached to the cornea. The distinctive architecture of the ciliary body is absent (compare $G$ to $H$, arrows). The $\mathrm{P} 21$ lens $(B)$ appears smaller, as it is not a midsagittal section through the lens. $c b$, Ciliary body. $c$, Cornea. $i$, Iris. $l$, Lens. $r$, Retina. $s$, Stroma. Scale bars $=100 \mu \mathrm{m}$.

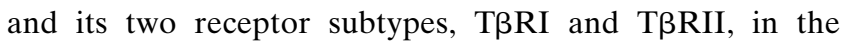
mouse eye.

In eyes of E15 mice (Fig. 7), using an antisense riboprobe to rat TGF- $\beta 1$, the endogenous message for TGF- $\beta 1$ was detected predominantly in the hyaloid vasculature surrounding the lens and lining the inner cell layer of the retina (Fig. $7 \mathrm{~B}$ ), and also in the vasculature of the choroid. Expression of TGF- $\beta 1$ was also detected in the anterior optic cup, which will later form the iris and ciliary body, and in the mesenchymal cells of the overlying eyelids (Fig. $7 \mathrm{~B}$ ). No specific expression was observed in the lens or neural retina. Using a sense riboprobe, no specific hybridization above background levels could be detected in ocular tissues (Fig. $7 A$ ).

Endogenous expression of T $\beta R I$ and T $\beta$ RII in eyes of E15 mice showed some overlap with the expression of TGF- $\beta 1$. T $\beta R I I$ is expressed in the hyaloid vasculature and in the cor- nea, the anterior optic cup, and the mesenchymal cells surrounding the eye (Fig. $8 \mathrm{~B}$ ). No significant expression was observed in the lens. T $\beta$ RI was also expressed at significant levels in the anterior optic cup (Fig. $8 \mathrm{D}$ ). Lower levels of T $\beta$ RI expression were detected in most ocular tissues, including the lens epithelial and fiber cells, the cornea, and the inner ganglion cell layer of the retina (Fig. $8 D$ ). As for T $\beta$ RII, T $\beta$ RI expression was detected in the mesenchymal cells surrounding the eye (Fig. $8 D$ ). Using sense riboprobes for T $\beta R I$ and TßRII, no significant levels of hybridization could be detected in any ocular tissues (Fig. 8, $A$ and $C$ ). Since a phenotype was observed in lenses of our transgenic mice by P21, we used immunohistochemistry to examine the expression of T $\beta R I$ and T $\beta$ RII at this age (Fig. 9). Using antibodies specific to T $\beta R I$ and T $\beta$ RII, strong labeling was observed in the lens epithelium and throughout the anterior subcapsular plaques in our trans- 


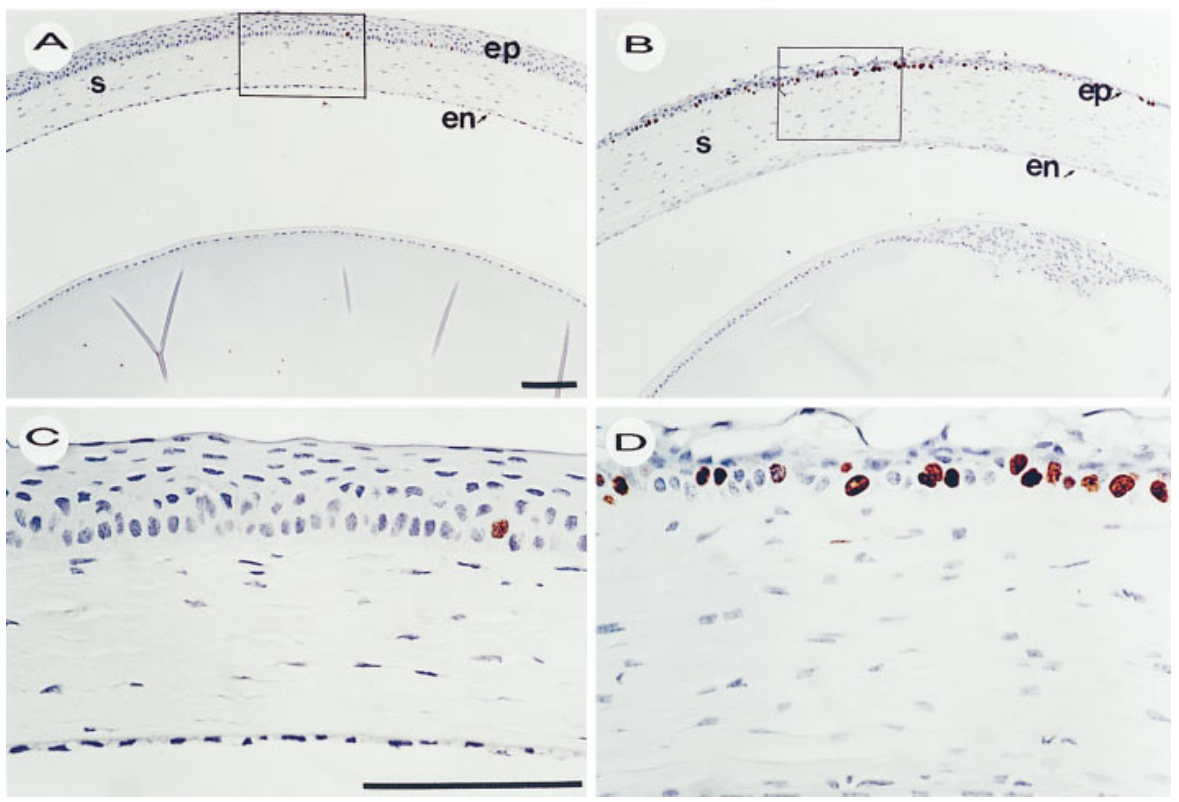

Figure 5. Incorporation of $\mathrm{BrdU}$ in $\mathrm{P} 21$ corneas. Mice from line OVE 853 were injected with BrdU and killed after $1 \mathrm{~h}$. Eyes were removed and processed for BrdU immunohistochemistry. Transgenic $(B)$ and nontransgenic $(A)$ eyes show significant BrdU labeling (dark nuclei) only in transgenic corneas. Boxed areas in $A$ and $B$ are shown in high power in $C$ and $D$, respectively. The labeled nuclei are in the basal cell layer of the corneal epithelium (ep). en, Corneal endothelium. $s$, Sclera. Scale bars $=100 \mu \mathrm{m}$. genic mice (Fig. 9). Expression patterns of TGF- $\beta$ receptors in nontransgenic eyes were similar to those observed in transgenic eyes, with significant staining for both receptor subtypes in the lens epithelium at P21 (data not shown).

\section{Discussion}

In this study, we have shown that in vivo expression of a selfactivating TGF- $\beta 1$ induces the formation of subcapsular plaques and cataracts in the lenses of transgenic mice. Differentiation of the cornea and ciliary body was also affected. The cataracts induced by the expression of TGF- $\beta 1$ have many similarities to human capsulolenticular cataracts, which include anterior subcapsular cataracts and anterior polar cata- racts $(20,21,23)$. These lenticular plaques are derived from the lens epithelium, and are comprised of spindle-shaped cells interspersed with accumulations of extracellular matrix. The lens capsule overlying the fibrotic plaque also acquires an irregular profile (see Fig. 6) indicative of the initial stages of capsule wrinkling (20). Moreover, $\alpha$-SMA, a protein not normally found in the lens and used as a marker for these forms of cataract (38), can be detected in the cells that comprise the plaque (see Fig. 6). Though all the cells of the lens epithelium express $\alpha$-SMA, we have observed that the central lens epithelial cells are the first to respond to TGF- $\beta 1$ to undergo the epithelial to mesenchymal transition. However, the peripheral lens epithelial cells also participate in plaque formation, resulting in a more severe phenotype at postnatal day 70 (data not shown).
CONTROL

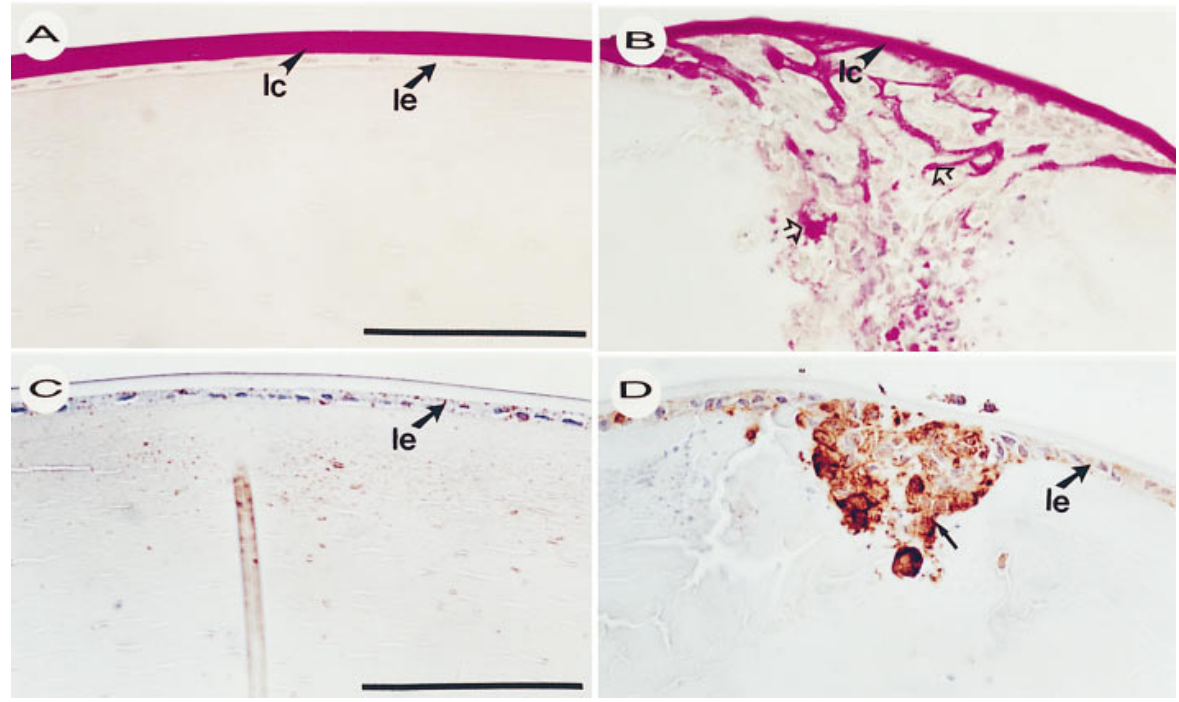

Figure 6. PAS staining and $\alpha$-SMA expression in the anterior subcapsular cataracts at P21. Sections from nontransgenic ( $A$ and $C)$ and transgenic lenses $(B$ and $D)$ were stained with PAS ( $A$ and $B$ ) or with an mAb to $\alpha$-SMA ( $C$ and $D$ ). A branching basement membrane indicating remodeling of the lens capsule $(l c)$ was present in transgenic lenses ( $B$, open arrows) but not in control lenses $(A)$. The fibrotic plaque stained intensely with the antibody to $\alpha$-SMA ( $D$, arrow). le, Lens epithelium. Scale bars $=100 \mu \mathrm{m}$. 

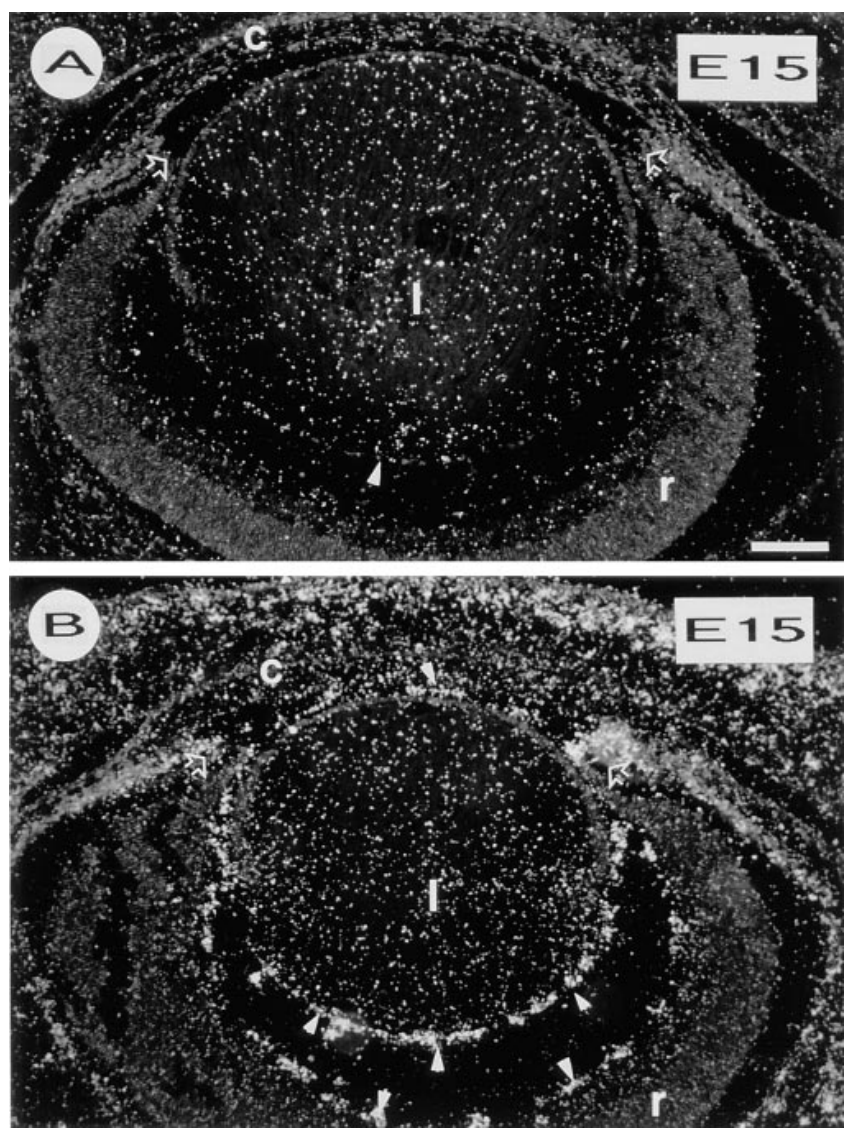

Figure 7. Expression of endogenous TGF- $\beta 1$ mRNA in the developing eye. Eyes from nontransgenic mice were assayed for TGF- $\beta 1$ mRNA by in situ hybridization, at E15, using sense $(A)$ or antisense $(B)$ probes. Sections are shown with dark field illumination. TGF- $\beta 1$ mRNA is detected in the hyaloid vasculature (arrowheads, $B$ ) and in
Additional intraocular signaling proteins may dictate the spatial and temporal patterns of cataract induction. The lack of staining in the subcapsular plaques with antibodies to $\beta$-crystallin, a marker of normal fiber cell differentiation (for a review, see reference 11), demonstrates that these spindleshaped cells are not differentiated lens cells.

Earlier in vitro studies have also presented strong support for a key role for TGF- $\beta$ in the etiology of cataracts (11). Initial studies revealed that TGF- $\beta$ induces cataract-like morphological changes in rat lens epithelial explants (25) as well as the accumulation of $\alpha$-SMA (40). Furthermore, whole rat lenses cultured in the presence of TGF- $\beta 2$ developed several distinct anterior subcapsular opacities containing abnormal depositions of ECM and expressing $\alpha$-SMA (24). Recent in vitro studies suggest that TGF- $\beta 2$ and- $\beta 3$ may be more potent than TGF- $\beta 1$ in inducing the formation of these opacities (GordonThomson, C., R.U. de Iongh, A.M. Hales, C.G. Chamberlain, and J.W. McAvoy, manuscript submitted for publication). The anterior opacities induced by TGF- $\beta$ s in these in vitro studies were similar to the ones obtained in the present study with some differences. The fibrotic plaques in our transgenic mice were polar and localized to the central anterior region of the lens. The defects observed in the development of the cornea, the iris, and ciliary body are also unique to the in vivo system. Since the ocular phenotype is not restricted to the lens, this indicates that our transgene-derived protein is secreted efficiently, and can influence nearby TGF- $\beta 1$-responsive ocular tissues, such as the cornea, iris, and ciliary body. As expected, high levels of TGF- $\beta 1$ LAP protein were detected by immuno-

the anterior optic cup (open arrows, $B$ ). No signals were detected using the sense strand probe $(A) . c$, Cornea. $l$, Lens. $r$, Retina. Scale bar $=100 \mu \mathrm{m}$.
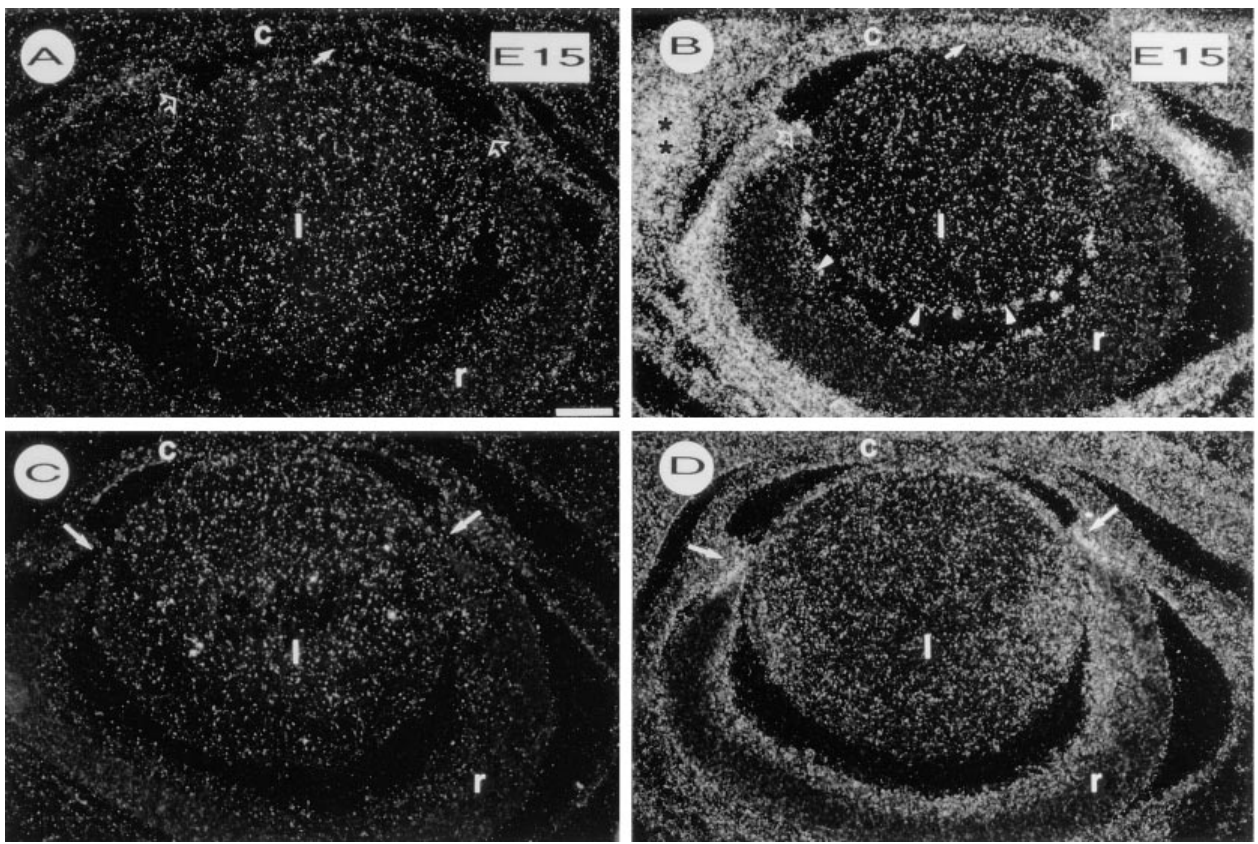

Figure 8. Expression of endogenous T $\beta R I$ and TßRII mRNAs in E15 eyes. T $\beta$ RII $(A$ and $B)$ and T $\beta R I(C$ and $D)$ transcription in normal E15 eyes was examined by in situ hybridization. Sections are shown with dark field illumination. $B$ and $D$ show hybridization using antisense probes. Cells in the hyaloid vasculature (arrowheads), the cornea (arrows), the anterior region of the optic cup (open arrows), and the embryonic mesenchymal cells (asterisks) express T $\beta R I I$, but no expression was detected in the lens. Weak expression of T $\beta R I$ was detected in the cornea, the anterior edge of the retina (arrows), the lens epithelium, and in mesenchymal cells surrounding the eye. $A$ and $C$ show hybridization using sense probes. $c$, Cornea. $l$, Lens. $r$, Retina. Scale bar $=100 \mu \mathrm{m}$. 


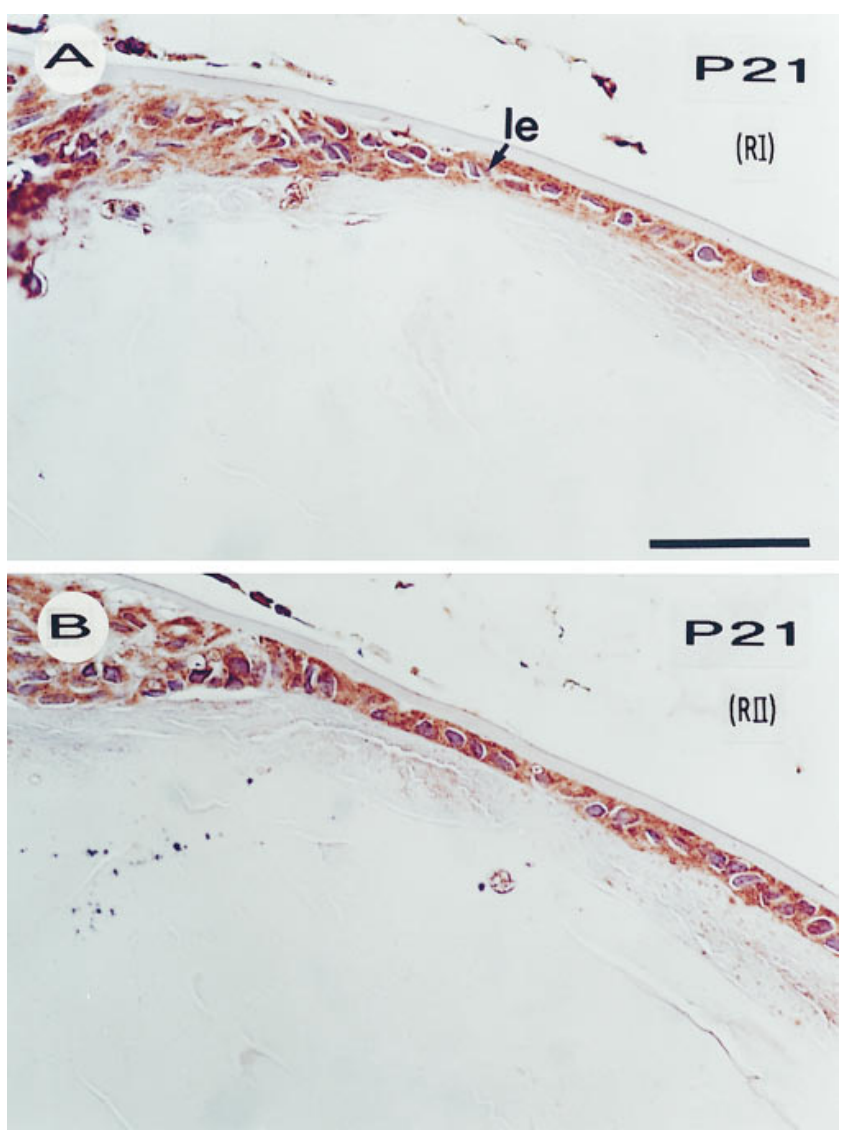

Figure 9. Immunohistochemistry of $\mathrm{P} 21$ lenses from transgenic family OVE 853 using T $\beta$ RI- and T $\beta$ RII-specific antibodies. Brown, Distribution of T $\beta$ RI $(A)$ and T $\beta$ RII $(B)$ protein in the lens. Lenses expressed high levels of both receptor proteins in the fibrotic plaques and in the lens epithelial cells (arrow). le, Lens epithelium. Scale bar $=100 \mu \mathrm{m}$.

histology in the transgenic lens (see Fig. 3). LAP was also detected in the anterior optic cup and in the RPE, confirming that the transgenic protein is secreted, and suggesting that nonneural cells of the optic cup either express receptors for LAP, or can bind the TGF- $\beta 1$ propeptide. T $\beta$ RII, the ligandbinding component of the heteromeric receptor complex, is expressed by these cells (see Fig. $8 \mathrm{~B}$ ).

TGF- $\beta 1$ LAP was also detected on the corneal epithelial cells of both transgenic and nontransgenic embryos (Fig. 3, $A$ and $B$ ), even though the endogenous mouse TGF- $\beta 1$ gene is not transcribed in the cornea (Fig. 7), in contrast to human TGF- $\beta 1$ (41). These results suggest that the nontransgenic E15 cornea, which is not covered by an eyelid and is therefore bathed in amniotic fluid, may be exposed to endogenous LAP. Based on the corneal alterations seen in the transgenic mice, we would suggest that this endogenous TGF- $\beta$ must be mostly latent. The normal corneal epithelium is in a continuous state of turnover, with the exfoliating apical squamous cells constantly being replaced by cells derived from the proliferating limbal basal cells. Exposure to activated TGF- $\beta 1$ in the transgenic mice leads to a dramatic increase in DNA synthesis in the basal cells (Fig. $5 \mathrm{D}$ ). A concomitant enhanced exfoliation of the squamous cell layer produces a thin opaque corneal epithelium (see Figs. 4 and 5). Whether the proliferation is a re- sponse to the exfoliation, or vice versa, remains to be determined. Although some in vitro studies have shown that TGF- $\beta$ can inhibit corneal epithelial cell growth (42), TGF- $\beta$ can also stimulate corneal epithelial cell growth in the presence of NIH $3 \mathrm{~T} 3$ cells or limbal fibroblasts, possibly by upregulation of basic FGF, which could act on the corneal epithelial cells in a paracrine manner (43). Although TGF- $\beta 1$ and its receptors are normally expressed in the presumptive iris and ciliary body (anterior optic cup, see Figs. 7 and 8), increased levels of TGF$\beta 1$ early in ocular development appear to disrupt the normal differentiation of the ciliary body and growth of the iris. These developmental defects in the cornea, iris, and ciliary body in our transgenic mice warrant further investigation. In human anterior subcapsular cataracts, the iris is often attached to the polar cataract at the pupillary margin (23). We did not observe the attachment of the iris to the cataracts in our transgenic mice. However, we did reproducibly see the adhesion of the iris to the overlying corneal endothelium and stroma (see Fig. $4 F$ ).

Despite the early expression of TGF- $\beta 1 \mathrm{mRNA}$ (Fig. 2) and protein (Fig. 3), the absence of a phenotype in lenses from E15 and newborn TGF- $\beta 1$ transgenic mice suggested that the TGF- $\beta 1$ receptors (T $\beta R I$ and T $\beta$ RII) may have a temporal pattern of expression different from that of the transgene. Our results using in situ hybridizations show that during embryonic development, although both these TGF- $\beta$ receptors are expressed in the anterior optic cup and in most mesenchymal cells around the eye, T $\beta$ RII is not expressed in the lens at detectable levels (Fig. 8). Later in development, significant levels of both receptors are detected in the lens epithelial cells (see Fig. 9). Cells in the lenticular plaques express high levels of the TGF- $\beta$ receptors. Recent immunohistochemical studies in rat lenses also support these findings, with negligible expression of T $\beta R I$ and T $\beta$ RII detectable in the epithelium at postnatal day 3 , but significant expression of both receptor types by postnatal day 21 (44). Thus, expression of the TßRII in the lens appears to be developmentally regulated. There is considerable evidence to indicate that a heteromeric complex of the two receptor types is essential to initiate the downstream effects of TGF- $\beta 1$, T $\beta$ RII being essential for ligand binding and T $\beta$ R for signal transduction (8). At E15, the lens epithelial cells express T $\beta R I$ but do not respond to TGF- $\beta 1$ because T $\beta R I I$ is not expressed. Therefore, the lens remains normal at E15. By P21, the epithelial cells express both types of TGF- $\beta$ receptor, and subcapsular cataracts form in response to exposure to active TGF- $\beta 1$. Earlier in vitro studies (24) support this model. Lens explants prepared from P21 or adult rats undergo cataract-like changes in response to TGF- $\beta$, whereas there are no obvious effects on explants prepared from 10-d-old lenses (24). Overall, it appears that eyes from older animals are more susceptible to the effects of TGF- $\beta$, suggesting that inappropriate TGF- $\beta$ activation may be a common factor in adult-onset cataract formation.

Various levels of active and latent forms of TGF- $\beta$ have been reported in ocular tissues and media from several mammalian species $(12,13,45,46)$. TGF- $\beta 1$ is expressed during early development of the eye, predominantly in the hyaloid vasculature surrounding the lens (see Fig. $7 \mathrm{~B}$ ) from which it is most possibly secreted into the ocular media. In adults, significant levels of TGF- $\beta$ are found in the aqueous humor, mainly in a latent form (15). The TGF- $\beta$ in the aqueous humor may be derived as an ultrafiltrate from the blood (15) or produced lo- 
cally by cells of the iris, ciliary body, and/or trabecular meshwork $(47,48)$. Although low levels of biologically active TGF- $\beta$ have been detected in ocular media from normal human eyes, increased levels are associated with patients suffering from various types of cataracts (45) and in intraocular fibrosis, a frequent complication of retinal detachment surgery (46). In this study, overexpression of an active form of TGF- $\beta$ in the eye results in several ocular defects. This suggests that most of the endogenous TGF- $\beta$ in the ocular media normally exists as a latent form and there is a need for tight regulation of the levels of active TGF- $\beta$.

In several biological systems, TGF- $\beta$ activated in response to injury can act as a chemoattractant for monocytes (49), can induce the expression of $\alpha$-SMA in myofibroblasts (38), and can enhance the synthesis and deposition of $\operatorname{ECM}(50,51)$. The cataractous changes induced in response to TGF- $\beta 1$ in our transgenic mice are similar to the changes that take place during wound healing, with the subcapsular cataracts reminiscent of scar tissue that would normally form in other tissues. In fact, early studies have shown that injury to the lens can induce the appearance of spindle-like cells and the deposition of ECM $(52,53)$.

In summary, we have developed a transgenic mouse model in which expression of TGF- $\beta 1$ in the lens results in the formation of cataracts resembling human anterior subcapsular or polar cataracts. Since such cataracts often arise as a result of injury or after cataract surgery, it is possible that TGF- $\beta$ activated under these circumstances from the latent to mature form initiates the formation of the cataract. The transgenic mouse model described in this study may help elucidate the mechanisms by which TGF- $\beta 1$ can initiate this disease process, and may aid in the development of strategies to prevent the formation of these types of human cataracts.

\section{Acknowledgments}

We thank Dr. Rik Derynck for mutant human TGF- $\beta 1$ cDNA, Dr. Michael Sporn for rat wild-type TGF- $\beta 1$ cDNA clones, and Dr. Naoto Ueno for T $\beta$ RI and T $\beta$ RII clones. We also thank Gaby Schuster for excellent technical assistance in the generation of transgenic mice, and Long Vien for meticulous animal husbandry. The help provided by Barbara Harris in the histological procedures is gratefully acknowledged.

This work was supported by grants from the National Eye Institute (EY-10448) and the Knight's Templar Foundation.

\section{References}

1. Roberts, A.B., and M.B. Sporn. 1990. The transforming growth factor- $\beta$ s. In Growth Factors and Their Receptors. Handbook of Experimental Pharmacology. A.B. Roberts and M.B. Sporn, editors. Springer-Verlag, Heidelberg. 419-472.

2. Derynck, R., 1994. TGF- $\beta$-receptor mediated signaling. Trends Biochem. Sci. 20:548-553.

3. Derynck, R., 1994. The biological complexity of transforming growth factor $\beta$. In The Cytokine Handbook. 2nd ed. A. Thompson, editor. Academic Press, Inc., New York. 319-342.

4. Ohta, M., J.S. Greenburg, P. Ankelesaria, A. Bassols, and J. Massague. 1987. Two forms of transforming growth factor $\beta$ distinguished by multipotential haematopoietic progenitor cells. Nature. 329:539-542.

5. Gentry, L.E., N.R. Webb, G.J. Lim, A.M. Brunner, J.E. Ranchalis, D.R. Twardzik, M.N. Lioubin, H. Marquardt, and A.F. Purchio. 1987. Type 1 transforming growth factor $\beta$ : amplified expression and secretion of mature and precursor polypeptides in Chinese hamster ovary cells. Mol. Cell Biol. 7:3418-3427.

6. Sato, Y., R. Tsuboi, R. Lyons, H. Moses, and D.B. Rifkin. 1990. Characterization of the activation of latent TGF- $\beta$ by co-cultures of endothelial cells and pericytes or smooth muscle cells: a self-regulating system. J. Cell Biol. 111:
757-763.

7. Lyons, R.M., L.E. Gentry, A.F. Purchio, and H.L. Moses. 1990. Mechanism of activation of latent recombinant transforming growth factor $\beta 1$ by plasmin. J. Cell Biol. 110:1361-1367.

8. Wrana, J.L., L. Attisano, R. Wieser, F. Ventura, and J. Massague. 1994. Mechanism of activation of the TGF- $\beta$ receptor. Nature. 370:341-347.

9. Massague, J. 1996. TGF- $\beta$ signaling: receptors, transducers, and Mad proteins. Cell. 85:947-950.

10. Montesano, R., and L. Orci. 1988. Transforming growth factor $\beta$ stimulates collagen-matrix contraction by fibroblasts: implications for wound healing. Proc. Natl. Acad. Sci. USA. 85:4894-4897.

11. Chamberlain, C.G., and J.W. McAvoy. 1997. Fiber differentiation and polarity in the mammalian lens. A key role for FGF. Prog. Ret. Eye Res. 16:443478 .

12. Pasquale, R.L., M.L. Dorman-Pease, G.A. Lutty, H.A. Quigley, and H.D. Jampel. 1993. Immunolocalization of TGF- $\beta 1$, TGF- $\beta 2$, and TGF- $\beta 3$ in the anterior segment of the human eye. Investig. Ophthalmol. Vis. Sci. 34:23-30.

13. Pelton, R.W., B. Saxena, M. Jones, H.L. Moses, and L.I. Gold. 1991. Immunohistochemical localization of TGF- $\beta 1$, TGF- $\beta 2$ and TGF- $\beta 3$ in the mouse embryo: expression patterns suggest multiple roles during embryonic development. J. Cell Biol. 115:1091-1105.

14. Lutty, G., K. Ikeda, C. Chandler, and D.S. McLeod. 1991. Immunohistochemical localization of transforming growth factor $\beta$ in human photoreceptors. Curr. Eye Res. 10:61-74.

15. Cousins, S.W., M.M. McCabe, D. Danielpour, and J.W. Streilein. 1991. Identification of transforming growth factor-beta as an immunosuppressive factor in aqueous humor. Investig. Ophthalmol. Vis. Sci. 32:2201-2211.

16. Millan, F.A., F. Denhez, P. Kondaiah, and R.J. Akhurst. 1991. Embryonic gene expression patterns of TGF $\beta 1, \beta 2$ and $\beta 3$ suggest different developmental functions in vivo. Development (Camb.). 111:131-144.

17. Dudley, A.T., K.M. Lyons, and E.J. Robertson. 1995. A requirement for bone morphogenetic protein-7 during development of the mammalian kidney and eye. Genes Dev. 9:2795-2807.

18. Luo, G., C. Hofmann, A.L. Bronckers, M. Sohocki, A. Bradley, and G. Karsenty. 1995. BMP-7 is an inducer of nephrogenesis, and is also required for eye development and skeletal patterning. Genes Dev. 9:2808-2820.

19. Sanford, P.L., I. Ormsby, A.C. Gittenberger-de-Groot, H. Sariola, R. Friedman, G.P. Bolvin, E.L. Cardell, and T. Doetschman. 1997. TGF- $\beta 2$ knockout mice have multiple developmental defects that are non-overlapping with other TGF- $\beta$ knockout phenotypes. Development (Camb.). 124:2659-2670.

20. Font, R.L., and S. Brownstein. 1974. A light and electron microscopic study of anterior capsular cataracts. Am. J. Ophthalmol. 78:972-984.

21. Novotny, G.E.K., and H. Pau. 1984. Myofibroblast-like cells in human anterior capsular cataract. Virchows Arch. A. Pathol. Anat. Histopathol. 404: 393-401.

22. Green, W.R., and P.J. McDonnell 1985. Opacification of the posterior capsule. Trans. Ophthalmol. Soc. UK. 104:727-739.

23. Worgul, B.V. 1993. Lens. In Biomedical Foundations of Ophthalmology. Vol. 15. T.D. Duane and E. Jaeger, editors. Harper \& Row, Philadelphia. $1-15$.

24. Hales, A.M., C.G. Chamberlain, and J.W. McAvoy. 1995. Cataract induction in lenses cultured with transforming growth factor- $\beta$. Investig. Ophthalmol. Vis. Sci. 36:1709-1713.

25. Liu, J., A. Hales, C.G. Chamberlain, and J.W. McAvoy. 1994. Induction of cataract-like changes in rat lens epithelial explants by transforming growth factor $\beta$. Investig. Ophthalmol. Vis. Sci. 35:388-401.

26. Arrick, B.A., A.R. Lopez, F. Elfman, R. Ebner, C.H. Damsky, and R. Derynck. 1992. Altered metabolic and adhesive properties and increased tumorigenesis associated with the increased expression of transforming growth factor $\beta 1$. J. Cell Biol. 118:715-726.

27. Brunner, A.M., H. Marquardt, A.R. Malacko, M.N. Lioubin, and A.F. Purchio. 1989. Site-directed mutagenesis of cysteine residues in the pro region of the transforming growth factor $\beta 1$ precursor. Expression and characterization of mutant proteins. J. Biol. Chem. 264:13660-13664.

28. Reneker, L.W., D.W. Silversides, K. Patel, and P.A. Overbeek. 1995 TGF- $\alpha$ can act as a chemoattractant to perioptic mesenchymal cells in developing mouse eyes. Development (Camb.). 121:1669-1680.

29. Overbeek, P.A., A.B. Cheplinsky, J.S. Khillan, J. Piatigorsky, and H. Westphal. 1985. Lens-specific expression and developmental regulation of the bacterial chloramphenicol acetyltransferase gene driven by the murine alpha A-crystallin promoter in transgenic mice. Proc. Natl. Acad. Sci. USA. 82:78157819.

30. Gorman, C.F., L.F. Moffat, and B.H. Howard. 1982. Recombinant genomes which express chloramphenicol acetyltransferase in mammalian cells. Mol. Cell. Biol. 2:1044-1051.

31. Taketo, M., A.C. Schroeder, L.E. Mobraaten, K.B. Gunning, G. Hanten, R.R. Fox, T.H. Roderich, C.L. Stewart, F. Lilly, C.T. Hansen, and P.A. Overbeek. 1991. FVB/N: an inbred mouse strain preferable for transgenic analysis. Proc. Natl. Acad. Sci. USA. 88:2065-2069.

32. Hogan, B., R. Beddington, F. Constantini, and E. Lacy. 1994. Manipulating the Mouse Embryo: A Laboratory Manual. 2nd ed. Cold Spring Harbor Laboratory, Cold Spring Harbor, NY. 
33. Robinson, M.L., P.A. Overbeek, D.J. Verran, W.E. Grizzle, C.R. Stockard, R. Friesel, T. Maciag, and J.A. Thompson. 1995. Extracellular FGF-1 acts as a lens differentiation factor in transgenic mice. Development (Camb.). 121: 505-514.

34. Qian, S.W., P. Kondaiah, A.B. Roberts, and M.B. Sporn. 1990. Cloning of a rat TGF- $\beta 1$ cDNA. Nucleic. Acids Res. 18:3059.

35. Suzuki, A., N. Shioda, T. Maeda, M. Tada, and N. Ueno. 1994. A mouse TGF- $\beta$ type I receptor that requires type II receptor for ligand binding. Biochem. Biophys. Res. Commun. 198:1063-1069.

36. Suzuki, A., N. Shioda, T. Maeda, M. Tada, and N. Ueno. 1994. Cloning of an isoform of mouse TGF- $\beta$ type II receptor gene. FEBS (Fed. Eur. Biochem. Soc.) Lett. 355:19-22.

37. Fromm, L., W. Shawlot, K. Gunning, J.S. Butel, and P.A. Overbeek. 1994. The retinoblastoma protein-binding region of simian virus 40 large $\mathrm{T}$ antigen alters cell cycle regulation in lenses of transgenic mice. Mol. Cell. Biol. 14: $6743-6754$.

38. Schmitt-Graff, A., H. Pau, R. Spahr, H.M. Piper, O. Skalli, and G. Gabbiani. 1990. Appearance of alpha-smooth muscle actin in human eye lens cells of anterior capsular cataract and in cultured bovine lens-forming cells. Differentiation. 43:115-122.

39. Gavrieli, Y., Y. Sherman, and S.A. Ben-Sasson. 1992. Identification of programmed cell death in situ via specific labeling of nuclear DNA fragments. J. Cell Biol. 119:493-501.

40. Hales, A.M., M.W. Schulz, C.G. Chamberlain, and J.W. McAvoy. 1994 TGF- $\beta 1$ induces lens cells to accumulate $\alpha$-smooth muscle actin, a marker for subcapsular cataracts. Curr. Eye Res. 13:885-890.

41. Nishida, K., C. Sotozono, W. Adachi, S. Yamamoto, N. Yokoi, and S. Kinoshita. 1995. Transforming growth factor $\beta-1, \beta-2$ and $\beta-3$ mRNA express in human cornea. Curr. Eye Res. 14:235-241.

42. Mishima, H., M. Nakamura, J. Murakami, T. Nishida, and T. Otori. 1992. Transforming growth factor $\beta$ modulates effects of epidermal growth factor in corneal epithelial cells. Curr. Eye Res. 11:691-696.
43. Tseng, S., J. Merritt, F. Ding, and D. Li. 1993. Mechanism of TGF- $\beta$ paradox in epithelial growth. Investig. Ophthalmol. Vis. Sci. 34:1302-1310.

44. de Iongh, R.U., C. Gordon-Thomson, C.G. Chamberlain, and J.W. McAvoy. 1996. Age related competence of TGF- $\beta$ response in rat lens epithelium correlates with receptor expression. Investig. Ophthalmol. Vis. Sci. 37: S983. (Abstr.)

45. Jampel, H.D., N. Roche, W.J. Starks, and A.B. Roberts. 1990. Transforming growth factor- $\beta$ in human aqueous humor. Curr. Eye Res. 9:963-969.

46. Connor, T.B., A.B. Roberts, M.B. Sporn, D. Danielpour, L.L. Dart, R.G. Michels, S. de Bustros, C. Enger, H. Kato, M. Lansing, et al. 1989. Correlation of fibrosis and transforming growth factor- $\beta$ type 2 levels in the eye. $J$. Clin. Invest. 83:1661-1666.

47. Helbig, H., K.L. Kittredge, M. Coca-Prados, J. Davis, A.G. Palestine, and R.B. Nussenblatt. 1991. Mammalian ciliary body epithelial cells in culture produce transforming growth factor beta. Graefe's Arch. Clin. Exp. Ophthalmol. 229:84-87.

48. Knisely, T.L., P.A. Bleicher, C.A. Vibbard, and R.D. Granstein. 1991. Production of latent transforming growth factor beta and other inhibitory factors by cultured murine iris and ciliary body cells. Curr. Eye Res. 10:761-771.

49. Wahl, S.M., D.A. Hunt, L.M. Wakefield, N. McCartney-Francis, L.M Wahl, A.B. Roberts, and M.B. Sporn. 1987. Transforming growth factor type $\beta$ induces monocyte chemotaxis and growth factor production. Proc. Natl. Acad. Sci. USA. 84:5788-5792.

50. Roberts, A.B., and M.B. Sporn. 1993. A major advance in the use of growth factors to enhance wound healing. J. Clin. Invest. 92:2565-2566.

51. Shah, M., D.M. Foreman, and M.W. Ferguson. 1994. Neutralizing antibody to TGF-beta 1,2 reduces cutaneous scarring in adult rodents. J. Cell Sci. 107:1137-1157.

52. Rafferty, N.S. 1973. Experimental cataract and wound healing in the mouse lens. Investig. Ophthalmol. 12:156-160.

53. Uga, S. 1981. Wound healing in the mouse lens. Exp. Eye Res. 322: $175-186$. 